\title{
IAMJ
}

INTERNATIONAL

AYURVEDIC

MEDICAL JOURNAL

\section{AN AYURVEDIC APPROACH ON VIPADIKA KUSHTA}

\section{Sruthi Sreedhar}

PG Scholar, Department of Kayachikitsa, KVG Ayurveda Medical College, Sullia, Karnataka, India

Corresponding Author: dr.sruthi.sreedhar@gmail.com

\section{https://doi.org/10.46607/iamj4709072021}

(Published Online: July 2021)

Open Access

(C) International Ayurvedic Medical Journal, India 2021

Article Received: 25/06//2021 - Peer Reviewed: 03/07/2021 - Accepted for Publication: 04/07/2021

\section{Check for updates}

\section{ABSTRACT}

Good skin is an integral part of health. In the present era, skin diseases are becoming a major hazard for mental health more than physical harm as it attributes the cosmetic harmony. Skin diseases are the outcome of improper food habits and lifestyles. Ayurveda has described all the skin diseases under the heading of Kushta. It is further divided into Maha Kushta and Kshudra Kushta. Vipadika is a common disorder of skin mentioned under Kshudraroga characterized by fissures and cracks in the hand and feet with severe pain. ${ }^{1}$ Vata Kapha Dosha is involved in this disease. The main features are Panipada Sputana along with Kandu, Thivravedana and Raga. ${ }^{2}$ It can be compared with palmoplantar psoriasis in modern science. It is an auto-immune condition, characterized by red scaly patches on palm and soles often with fissures and bleeding. Ayurvedic treatment is very effective in these conditions. A 49-year-old male patient came to KVG Ayurveda Medical College, KC, OPD with complaints of itching, scaly lesion and pain in palms and soles, for 4 months. According to Lakshanas, it is diagnosed as Vipadika and treated with Shodhana, Shamana and Rasayana Oushadis and the patient got good relief. Ayurvedic treatment is very effective in the management of skin diseases because Ayurveda removes Doshas from its root. The present case study proves the Ayurvedic management of Vipadika Kushta is very effective with promising results.

Keywords: Vipadika Kushta, palmo plantar psoriasis, Shodana, Shamana, Rasayana. 


\section{INTRODUCTION}

Vipadika is a common disorder of skin mentioned under Kshudraroga. Main symptoms of Vipadika include Panipadasputana along with Kandu, Vedana and Raga. Specific Nidana is not available for Vipadika. In the present case study Kushta Samanya Nidana like excess use of Dadhi, Mathsya, Amla and Lavana Ahara are found. Samanya Kushta Purvarupa is considered as Poorvarupa of Vipadika as a separate explanation is not seen. In Vipadika,Vata Kapha Pradhana,Tridosa Prakopa Nidana is seen.Vyaktha Sthana is mainly Pada and Hasta. The majority of Lakshanas like Sphutana, Vedana are due to increased Rukshaguna of Vata. Kandu is due to Kapha. Daha due to Pitta. When the Twak and Mamsa undergo Dharana there will be Rakthasrava and Sputana as it lies above the Mamsadhara Kala. Along with Kushta Chikitsa, specific Chikitsa is explained for Vipadika. Acharya Charaka explained all Kushta are Tridoshaja, so the treatment is according to the predominance of Dosha. The predominant Dosha should be treated first and the treatment of other subordinate Doshas should be undertaken afterwards. Nidana Parivarjana is a very important factor in the treatment. It stops the further progression of the disease by restricting Dosha vitiation. In the present case, the study patient doesn't have any special nidana, Kushta Nidanas like Virudhahara Sevana etc are seen. Samshodana is explained for Kushta management because Kushta Rogi is Bahudoshi because of Dosha vitiation to the greatest extent. In Vata predominance, the Sarpi Pana, in Pitta predominance Virechana and Raktha Mokshana and Kapha Vamana is indicated by classics . ${ }^{3}$

Shamana Chikitsa plays an important role in the treatment of Kushta. After the Shodhana procedure, Shamana measures are indicated to cure the residual vitiated Dosha. It is very useful in those patients who are unable to undergo or contraindicated for Shodhana procedure.

Shamana therapy mainly in the form of internal medication is advised to get rid of the vitiated Dosha as well as to provide Bala to prevent the reoccurrence of the disease. External application is very important. Symptoms of Vipadika are similar to palmoplantar psoriasis in contemporary science. Psoriasis is a chronic inflammatory skin disease. Palmoplantar psoriasis is a type of psoriasis that affects the palms of the hands and the soles of the feet. It is an autoimmune condition. This paper discusses the effectiveness and potential of the Ayurvedic management of Vipadika Kushta.

\section{Case Report:}

49-year-old male patient came to our KVG Ayurveda Medical College KC, OPD, with c/o of welldemarcated raised scaling of both palms and soles with severe itching and pain for 4 months. Also complained, peeling of skin at the point of disruption of hand, soles and knee joints.

\section{History of past illness}

The patient was well before 8 years, initially itching appeared on the leg then all over the body, then the patient took homoeopathic treatment got relief. Presently, a patient complaint about pain, itching and scaly lesions on the palms and soles, also the knee joint and elbow joint.

Treatment history: H/o HB

Family history: The patient's sister has the same complaint.

\section{Vayakthika Vrithanta:}

Diet: Mixed diet, Excess intake of spicy things and non-veg, Bowel: Constipated, Appetite: Poor, Sleep: Sound.

\section{TRIVIDHA PAREEKSHA}

Darshana: Mathysa Shakalopama, Vaivarnatha, Sputana., Sparshana: Ushna,KharaSparsha, Prashna: Kandu, Daha, Thoda

ASHTASTHANA PAREEKSHA

Nadi: Vata-Kapha, Muthra: 5 to 6 times per day. Mala: BadhaMala., Jihwa: Aliptha., Shabda: Sparsha, Sparsha: AnusnaSparsha., Drik: Vikritha., Akrithi: Madyama

DASAVIDHA PAREEKSHA

Prakrithi: Vata-Kapha., Vikrithi: Rasa, Raktha, Twak, Mamsa., Sathwa: Madhyama., Sara: Rasa Sara ., 
Samhanana: Madhyama., Pramana: Madhyama., Sathmya: Katu, Amla, Lavana., AharaShakthi: Avara., VyayamaShakthi: Uthama., Vaya: Madyama

NIDANA PANCHAKA

Nidana: excessive intake of fish, chicken,spicy foods, excess Lavana intake., Purvarupa: Kandu., Rupa:
MathyaShakalopama, Kandu, Vedana, Sputana, Vaivarnya., Upashaya: UshnaJala., Anupashaya: Sheetha kala

Samprapti:

Nidana $\longrightarrow$ Vatakaphaprakopa $\longrightarrow$ Rasavaha, Rakthavaha. Swedovaha Srothodushti $\longrightarrow$ Sanga and Vimaravamana of Doshas $\longrightarrow$ Padahastha Dosha sthanasamsraya $\longrightarrow$ vipadika

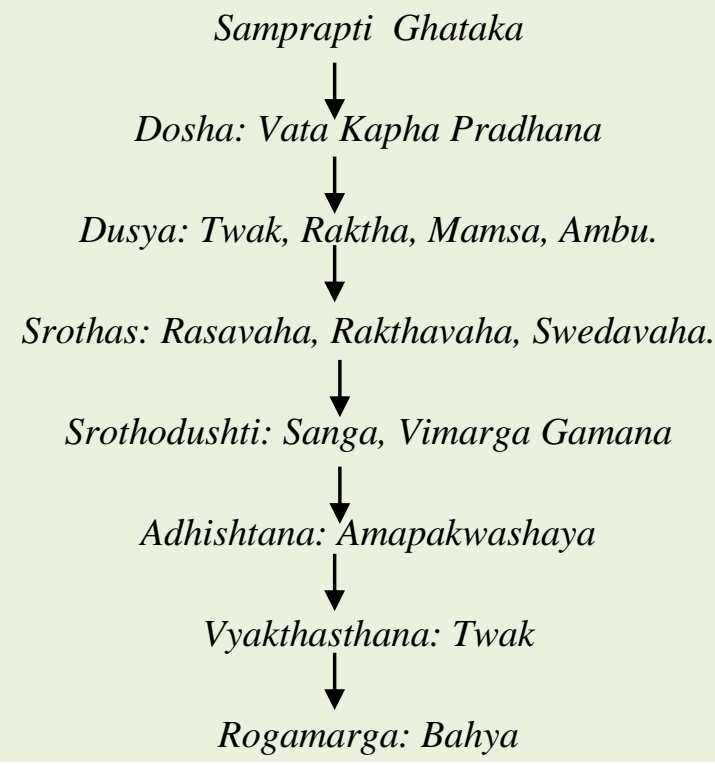

\section{General Examination}

BP-: $140 / 90 \mathrm{~mm}$ of $\mathrm{Hg}$, Pulse rate-: 78/min, Respiratory rate-: 20/min, Height-:54kg, Edema/lymphadenopathy/pallor/icterous/cyanosis:

Absent

\section{Systemic Examination}

Respiratory Rate: NVBS, Cardiovascular System: S1, S2heard, P/A: soft tender, CNS: conscious and well oriented.

\section{Skin Examination}

Inspection: well-defined areas of raised thickened skin

Redness and scaling, cracks

Color: Blackish

Appearance: Rough dry and scaling

Discharge: mild bleeding

Lesions: Multiple
Palpation: Rough, Hard, temperature Normothermia, Tenderness absent

\section{Special Test}

Candle grease test ${ }^{+} \mathrm{ve}$

Auspitz sign ${ }^{+} \mathrm{ve}$ VyavachedanaNidana (Differential Diagnosis)

Charmadala, Kitiba, Vicharchika, Vipadika, Charmakhya

Vyadhivinischaya (Diagnosis)

Vipadika

Chikitsa

- Agnitundivati\&ChitrakadiVati for Deepana, Pachana \&Amapachana purpose.

- Mahatikthakam Gritham for Snehapana till Samyak Snigdhalakshanas observed.

- Virechana with Trivrithlehyam

- Samsarjana karma 
After, Shamanioushadi is given

- Patola -Katurohinyadi Kashayam 15ml kashayam with $60 \mathrm{ml}$ lukewarm water, morning and evening on empty stomach.

- Vilwadi tablet 2 - 0-2

- Khadirarishtam 30ml twice daily, after food.

- Jeevanthyadi Yamaka for external application after the medicated washing (Triphala)

\section{Follow up,}

- Gandhaka Rasayana

- Jivanthyadi lepa for application

$>$ Controlling body weight

$>$ Managing stress

$>$ Stop smoking

$>$ Reducing the direct exposure to detergents and chemicals.

\section{PATHYA APATHYA ${ }^{4}$}

Yava, Godhuma, Shali, Ghee, Tiktha Rasa

Should avoid the use of meat, milk, curd,Masha,

Kulatha, Divaswapna,

\section{DISCUSSIONS}

Mahatikthakam Gritham ${ }^{5}$ contain Saptaparna, Ativisha, Musta, Ushira, Triphala, Patola, Chandana, Pippali, Padmaka, Sathavari, sarivaa, Amritha, Murva etc. and here it is used for Snenana purpose, it is good for the management of all skin conditions. Trivritlehyam ${ }^{6}$ Trivrith is the main ingredient, and it is an ideal laxative drug that helps to eliminate Doshas from koshta. Triphala Prakshalana is very effective, it is Tridoshahara, Vranaropana. JeevanthyadiYamaka oilment ${ }^{7}$ contain Jivanthi, Manjishta, sesame oil, ghee, Arka and massage helps the blood to absorb the content of the Tailam directly into the skin and cure the skin ailments. Patolakaturohinyadi kashaya ${ }^{8}$ contains Patola, Katurohini, Chandana, Murva, Guduchi, Patha.it is Rakthaprasadaka, Deepana, Jwaraghna, helps in skin disorders. Patola, Katurohini, Guduchi which are Tiktharasa, Rakthashodaka and Kushtahara.Vilwadigulika ${ }^{9}$ contains Bilwa, Surasa, Karanja, Natam, Surahwam, Harithaki, Vibeethaki, Amalaki, Shunti, Maricha, Pippali, Haridra, Daruharidra which are processed in goat's urine. It is
Ttiktha and Katu in Rasa, Laghu and Ruksha in Guna. Ushna in virya. With kaphavathahara and vishaghna property. If any toxic material in the body will be less potent, slow-acting tends to stay in the body is given to remove any toxic materials from the body, antimicrobial immunomodulatory and antiinflammatory activity. Khadirarishtam ${ }^{10}$ ingredients Khadira, Devadaru, Bakuchi, Triphala, Darvi etc and it is very effective in skin conditions, regular use of this tonic purifies blood, reduces toxins production, regulates sebum production in the skin and inhibits bacterial growth. Arishta is Agnideepaka and Srothoshodaka and the Shodhana and Shamana treatment, the patient got a good result. After for Rasayana purpose, Gadhakarasayana is advised, which contain Sulphur. It is used for skin conditions for centuries. It strengthens the immune system and is kanduhara and kushtahara also prevent the reoccurrence of the disease. After the treatments, patient overall condition of health is improved.

\section{CONCLUSION}

Vata is the main cause of Vipadika. The Rooksha Guna of Vata causes severe dryness which finally leads to the formation of cracks. Vipadika is Vata Kaphaja Kshudraroga the Ushna Guna of medicine helps to pacify vitiated Vata Dosha and Kapha Dosa and directly counteract the respective symptoms like cracks, pain, itching. Bahirparimarjana Chikitsa is necessary for all skin diseases. Shodana is done by giving Mahatikthakam Gritha and Trivrith Lehyam after which the patient's skin becomes soft and the cracks reduced. No bleeding, pain and scaling are reduced. Washing with Triphala boiled in water and application of Jeevanthyadi Yamaka is very effective. Shamana Oushadis like Patola Katuroninyadi Kashayam, Vilwadi Gulika, Khadirarishtam is helped to enhance the patient's health condition.

Our body needs Sulphur to build and fix DNA and protect cells from damage that can lead to serious diseases such as cancer. Sulphur also assists the body to metabolize food and contribute to the health of the skin. Sulphur is the third most abundant element in the body, Amino acids like methionine and cysteine 
are present, both of these amino acids are present in skin hair and nails. Gandhaka Rasayana ameliorates skin conditions and prevents reoccurrence. After the treatment patients' overall quality of life was significantly improved.

\section{REFERENCES}

1. Acharya Agnivesa Charaka Samhitha edited by VaidyaJadavji Trikamji commentary with Ayurveda Deepikapublished by ChoukhambaSanskritsamsthan, Varanasi reprint 2011, Cikitsa stana $7^{\text {th }}$ chapter, sloka no 22 pages no 451.

2. Acharya Vagbhata, AshtangaHridaya Arunadatta, Sarvangasundara, Hemadri Ayurveda Rasayana edited by prof K.R. Srikantamurthy, published by Chaukhamba Krishna academy, Varanasi,9 th edition 2013, Nidana sthana, $14^{\text {th }}$ chapter, sloka no 23 , page no 139.

3. Pandeya Gangasahaya Edited, TheCharaka Samhitha of Agnivesa and Ayurveda Dipika commentary of Chakrapanidatta with Vidyotini Hindi commentary by Shatri Kashinath, part11, reprinted Varanasi, Chaukhamba Sansthan 2006,206 pp.

4. Susrutha, Susrutha Samhita Nibandhasangraha commentary of Dalhana and Nyaya Chandrika Panjika of Gayadasa, edited by Vaidya JadavjiTrikamji Acharya and Narayan Ram Acharya Kavithraya, ChoukambaOrientalia, Varanasi,Cikitsasthana 9th chapter, sloka no 4 to 5,p442.

5. Bhaishajyaratnavali By Govinda Das, published by Chaukhamba publishers, Kushtaadhikara 118-124

6. Ashtanga Hridaya with Sarvangasundara commentary of Arunadatta, Chaukhamba publication, Kalpasthana 2/9

7. Ashtanga Hridaya with Sarvangasundara commentary of Arunadatta, Chaukhamba publication

8. Ashtanga HridayawithSarvangasundara commentary of Arunadatta, Chaukhamba publication, Sutrasthana $15 / 15$,

9. Sahasrayogam with English translation by Dr.K Nishteswar and Dr.R . Vidyanath, Published by Chaukhamba publishers, Gutika Prakarana, page 323.

10. Sahasrayogam with English translation by Dr.K. Nishteswar and Dr.R. Vidyanath, Published by Choukhamba publishers, Arishtaprakarana, page 234

\section{Source of Support: Nil \\ Conflict of Interest: None Declared}

How to cite this URL: Sruthi Sreedhar: An Ayurvedic Approach On Vipadika Kushta. International Ayurvedic Medical Journal \{online\} 2021 \{cited July 2021\} Available from:

http://www.iamj.in/posts/images/upload/1603_1607.pdf 